\title{
Perinuclear Halo Present
}

National Cancer Institute

\section{Source}

National Cancer Institute. Perinuclear Halo Present. NCI Thesaurus. Code C96344.

A morphologic finding referring to the presence of a vacuolated area that surrounds the nucleus. It results from nuclear shrinking. 